\begin{tabular}{|l|l|l||}
\hline \multicolumn{2}{|c|}{ PublisherInfo } \\
\hline \hline PublisherName & $:$ & BioMed Central \\
\hline \hline PublisherLocation & $:$ & London \\
\hline \hline PublisherImprintName & $:$ & BioMed Central \\
\hline \hline
\end{tabular}

\title{
Tracking human origins
}

\begin{tabular}{|l|l|l||}
\hline \multicolumn{2}{|c|}{ ArticleInfo } \\
\hline \hline ArticleID & $:$ & 3854 \\
\hline \hline ArticleDOI & $:$ & $10.1186 /$ gb-spotlight-20001207-02 \\
\hline \hline ArticleCitationID & $:$ & spotlight-20001207-02 \\
\hline \hline ArticleSequenceNumber & $:$ & 291 \\
\hline \hline ArticleCategory & $:$ & Research news \\
\hline \hline ArticleFirstPage & $:$ & 1 \\
\hline \hline ArticleLastPage & $:$ & 2 \\
\hline \hline & & RegistrationDate : 2000-12-07 \\
ArticleHistory & $:$ & OnlineDate $\quad$ 2000-12-07 \\
\hline \hline ArticleCopyright & $:$ & BioMed Central Ltd2000 \\
\hline \hline ArticleGrants & $:$ & \\
\hline \hline ArticleContext & $:$ & 130591111 \\
\hline \hline
\end{tabular}




\section{William Wells}

Email: wells@biotext.com

Mitochondrial DNA (mtDNA) is ideal for evolutionary analysis because of lack of recombination, a high substitution rate, and maternal inheritance. Previous analyses have been limited to short stretches of mtDNA, but in the 7 December Nature Ingman et al. present results based on complete mtDNA sequences of 53 humans of diverse origins (Nature 2000, 408:708-713). The greater detail allows the derivation of a phylogenetic tree for the sequences. Two pieces of data (the genetic distance between human and chimpanzee mtDNA sequences, and the known time since these two species diverged) are used to calculate a mutation rate, which in turn allows dates to be assigned to branches of the human tree. The tree supports the idea of an African origin, with a most recent common ancestor 171,500 +/50,000 years ago. This was followed by a population bottleneck associated with the colonization of Eurasia from Africa.

\section{References}

1. Estimation of the number of nucleotide substitutions in the control region of mitochondrial DNA in humans and chimpanzees.

2. Nature, [http://www.nature.com/nature/]

This PDF file was created after publication. 